\title{
Multiple functions of autophagy in vascular calcification
}

\author{
Xin Zhou ${ }^{1 \dagger}$, Sui-Ning Xu ${ }^{2 \dagger}$, Shu-Tong Yuan ${ }^{1 \dagger}$, Xinjuan Lei ${ }^{3}$, Xiaoying Sun ${ }^{4}$, Lu Xing ${ }^{1}$, Hui-Jin Li ${ }^{1}$, Chun-Xia He ${ }^{1}$, \\ Wei Qin ${ }^{1}$, Dong Zhao ${ }^{1}$, Peng-Quan $\mathrm{Li}^{1}$, Edward Moharomd ${ }^{5^{*}}$, Xuehong $\mathrm{Xu}^{3^{*}}$ and Hui-Ling Cao ${ }^{{ }^{*}}$
}

\begin{abstract}
Background: Vascular calcification is a closely linked to cardiovascular diseases, such as atherosclerosis, chronic kidney disease, diabetes, hypertension and aging. The extent of vascular calcification is closely correlate with adverse clinical events and cardiovascular all-cause mortality. The role of autophagy in vascular calcification is complex with many mechanistic unknowns.
\end{abstract}

Methods: In this review, we analyze the current known mechanisms of autophagy in vascular calcification and discuss the theoretical advantages of targeting autophagy as an intervention against vascular calcification.

Results: Here we summarize the functional link between vascular calcification and autophagy in both animal models of and human cardiovascular disease. Firstly, autophagy can reduce calcification by inhibiting the osteogenic differentiation of VSMCs related to ANCR, ERa, $\beta$-catenin, HIF-1a/PDK4, p62, miR-30b, BECN1, mTOR, SOX9, GHSR/ERK, and AMPK signaling. Conversely, autophagy can induce osteoblast differentiation and calcification as mediated by CREB, degradation of elastin, and InCRNA H19 and DUSP5 mediated ERK signaling. Secondly, autophagy also links apoptosis and vascular calcification through AMPK/mTOR/ULK1, Wnt/B-catenin and GAS6/AXL synthesis, as apoptotic cells become the nidus for calcium-phosphate crystal deposition. The failure of mitophagy can activate Drp1, BNIP3, and NR4A1/DNA-PKcs/p53 mediated intrinsic apoptotic pathways, which have been closely linked to the formation of vascular calcification. Additionally, autophagy also plays a role in osteogenesis by regulating vascular calcification, which in turn regulates expression of proteins related to bone development, such as osteocalcin, osteonectin, etc. and regulated by mTOR, EphrinB2 and RhoA. Furthermore, autophagy also promotes vitamin K2-induced MC3T3 E1 osteoblast differentiation and FGFR4/FGF18- and JNK/complex VPS34-beclin-1-related bone mineralization via vascular calcification.

Conclusion: The interaction between autophagy and vascular calcification are complicated, with their interaction affected by the disease process, anatomical location, and the surrounding microenvironment. Autophagy activation

\footnotetext{
*Correspondence: edwh_mohard@jhmi.edu; xhx0708@snnu.edu.cn; caohuiling.jzs@xiyi.edu.cn

${ }^{\dagger}$ Xin Zhou, Sui-Ning Xu and Shu-Tong Yuan contributed equally to this work

${ }^{1}$ Shaanxi Key Laboratory of Ischemic Cardiovascular Disease, Shaanxi Key Laboratory of Brain Disorders, Institute of Basic \& Translational Medicine, Xi'an Medical University, Xi'an 710021, Shaanxi, China

${ }^{3}$ Laboratory of Cell Biology, Genetics and Developmental Biology, Shaanxi Normal University College of Life Sciences University Hospital Medical Center, Xi'an 710062, Shaanxi, China

5 Johns Hopkins University School of Medicine, Baltimore, MD 21205, USA

Full list of author information is available at the end of the article
} permits use, sharing, adaptation, distribution and reproduction in any medium or format, as long as you give appropriate credit to the original author(s) and the source, provide a link to the Creative Commons licence, and indicate if changes were made. The images or other third party material in this article are included in the article's Creative Commons licence, unless indicated otherwise in a credit line to the material. If material is not included in the article's Creative Commons licence and your intended use is not permitted by statutory regulation or exceeds the permitted use, you will need to obtain permission directly from the copyright holder. To view a copy of this licence, visit http://creativecommons.org/licenses/by/4.0/. The Creative Commons Public Domain Dedication waiver (http://creativeco mmons.org/publicdomain/zero/1.0/) applies to the data made available in this article, unless otherwise stated in a credit line to the data. 
in existent cellular damage is considered protective, while defective autophagy in normal cells result in apoptotic activation. Identifying and maintaining cells at the delicate line between these two states may hold the key to reducing vascular calcification, in which autophagy associated clinical strategy could be developed.

Keywords: Vascular calcification, Autophagy/mitophagy, Osteoblastic differentiation of VSMCs, Osteogenesis, AMPK/ mTOR, HIF-1a/PDK4, EphrinB2, GAS6/AXL

\section{Introduction}

Regarded as a common pathological manifestation of patients with atherosclerosis, chronic kidney disease (CKD), diabetes, hypertension, postmenopausal syndrome, aortic stenosis [1-3] and the aging population [4], vascular calcification (VC) significantly correlated with cardiovascular and all-cause mortality, via deleterious mechanical effects on vascular compliance and vasomotion [5, 6]. Pathological abnormalities of VC may cause further adverse cardiovascular events and even induce death. The importance of $\mathrm{VC}$ to human health has attracted more attention, but the molecular mechanism of $\mathrm{VC}$ is under further investigation.

As a fundamental process for degradation and recycling of exhausted cellular components prevalent in eukaryotes, autophagy has recently been recognized in various physiological and pathological events, which presents a unique mechanism of self-regulating/cleaning [7-9]. Briefly, as a survival mechanism within an intracellular degradation system, autophagy process is composed of numerous chronological steps including sequestration, transport to lysosomes, degradation of cytoplasmic components, and utilization of degradation products. This self-degradative process tightly associates with both physiological and pathological status within normal embryonic and postnatal development in the behaviors of microautophagy, macroautophagy, chaperone-mediated autophagy and other new discovered manners [10].

The autophagic mechanism tightly associates with critical signaling pathways including PI3K/AKT, MAPK/ Erk1/2, mTOR, AMPK, p53, HIF-1 $\alpha /$ PDK4, $\beta$-catenin, ULK and Atg involved in regulation of the cellular autophagy $[11,12]$. It has been intensely understood that autophagy functions in the cardiovascular diseases [13, 14], and the autophagic phenotype associated to vascular smooth muscle linking to steogenic differentiation [15], apoptosis [16], inflammation [17], Fibroblast Growth Factor 23 (FGF23)-Klotho [17, 18], Matrix Vesicle (MV) release [19], and oxidative stress [20] physiological or pathological conditions.

In both tumorigenesis and cardiovascular pathology, calcium $\left(\mathrm{Ca}^{2+}\right)$ is considerate to be an essential constituent vital to the healthy physiology and disease pathology of both tumor cells and myocytes [21-24]. In regulation of cellular proliferation and apoptotic death, AKT/
AMPK pathway control the cell cycle by targeting on critical point of $\mathrm{G} 2 / \mathrm{S}$ transition functioning along with Ras and Cyclin D1. With involvement of autophagic proteins including Beclin, LC3-1 and LC3-II, up-regulations of AMPK, phospholated pAKT and pmTOR powerfully link Akt/mTOR associated autophagy to osteogenic differentiation of human mesenchymal stem cells [25].

Recently, it confirmed that the VC process accompanies on expression alternation of vascular smooth muscle cells (VSMCs) contractile phenotype-related factors such as $\alpha$-SMA, calponin-1, SM22 $\alpha$ and others along with the imbalance of a variety of calcification promoting factors including ALP, Runx2, BMPs, OCN, Collagen I and their inhibitors [26, 27]. Osteoblasts derived from VSMCs and mesenchymal stromal cells (MSCs) are regulated by autophagy $[28,29]$ and promotes transition of calcification signals for mineralization in the vessel wall of the vascular structure [30-32]. Autophagy within the physiological range functions protective effect but pathologic autophagy generates excessively or less activation. In this paper, we elucidate that the clarification on the mechanism of autophagy regulated $\mathrm{VC}$ would provide valuable information for developing diagnostic strategy and anti$\mathrm{VC}$ drug design targeting on autophagy.

\section{Autophagy affects vascular calcification by interfering with the osteogenic differentiation of VSMCs}

As defined as an active, highly controllable mineral deposition process, the pathological changes of $\mathrm{VC}$ involve intima and middle layer of blood vessels, mainly VSMCs included in vessels-wall structure [33]. In the VC process, VSMCs transform from contractile phenotype to osteogenic/chondral phenotype directly or through synthetic inter-type [15]. Currently known related signaling pathways include ER $\alpha, \beta$-catenin, HIF-1a/PDK4, p62, miR30b, BECN1, mTOR, SOX9, GHSR/ERK, AMPK, Elastin [34-39]. The definite mechanism of osteoblastic differentiation of VSMCs is critical for vascular calcification.

\section{Autophagy reduces calcification by inhibiting the osteogenic differentiation of VSMCs}

Liang, et al. proved that long non-coding RNA-ANCR promoted the expression of LC3 and Atg5 in $\beta$-GP-induced VSMCs, and inhibited osteoblastic 
differentiation of VSMCs. The ANCR may attenuate arterial calcification through activating autophagy that inhibits osteogenic differentiation of VSMCs [40]. The autophagy inhibitor 3-MA or knockout of Atg5 increased calcium deposition, whereas the autophagy inducer valproic acid reduced VSMC calcification [31]. Yuan and colleagues approved that oestrogen inhibited the osteoblastic differentiation of VSMCs by promoting autophagy through the ER $\alpha$ but not ER $\beta$ signaling pathway [34].

Statins display various protective effects against VSMC proliferation and inflammation in cardiovascular remodeling [41] and inhibit calcification of atherosclerotic plaques in the apoE-deficient mice [42]. Results from clinical trials suggest an association of statins usage with slow progression of calcific aortic stenosis, and coronary artery calcification [43, 44]. Liu and colleagues found inhibitory effect of atorvastatin on calcification is caused by inducing autophagy by using 3-MA, chloroquine, $\mathrm{NH}_{4} \mathrm{Cl}$ and bafilomycin
A1. Their data approved that atorvastatin can protect VSMC differentiation from TGF- $\beta 1$-stimulated calcification through suppression of $\beta$-catenin pathway [35]. Their data are consistent with the recently results that atorvastatin could reduce arterial calcification and plasma calcium concentration [45] (Fig. 1).

Recently, it is approved that AGEs could increase alkaline phosphatase (ALP) and accelerate the calcification of VSMCs [46]. AGE-BSA treatment on VSMCs improved the expression of PDK4 via HIF- $1 \alpha$ upregulation. The AGE-BSA incubation promoted expression increase of LC3-II and decrease of p62 protein levels. The treatment could enhance autophagic flux mediated by mRFP-GFP-LC3 adenovirus, make co-localization of LC3-II and LAMP-1, and eventually augmenter the number of autophagosome under TEM. HIF-1a/PDK4 pathway was activated in the process of AGEs-induced autophagy of VSMCs, which reduced the expression of the Runt-related transcription factor (RUNX2) and

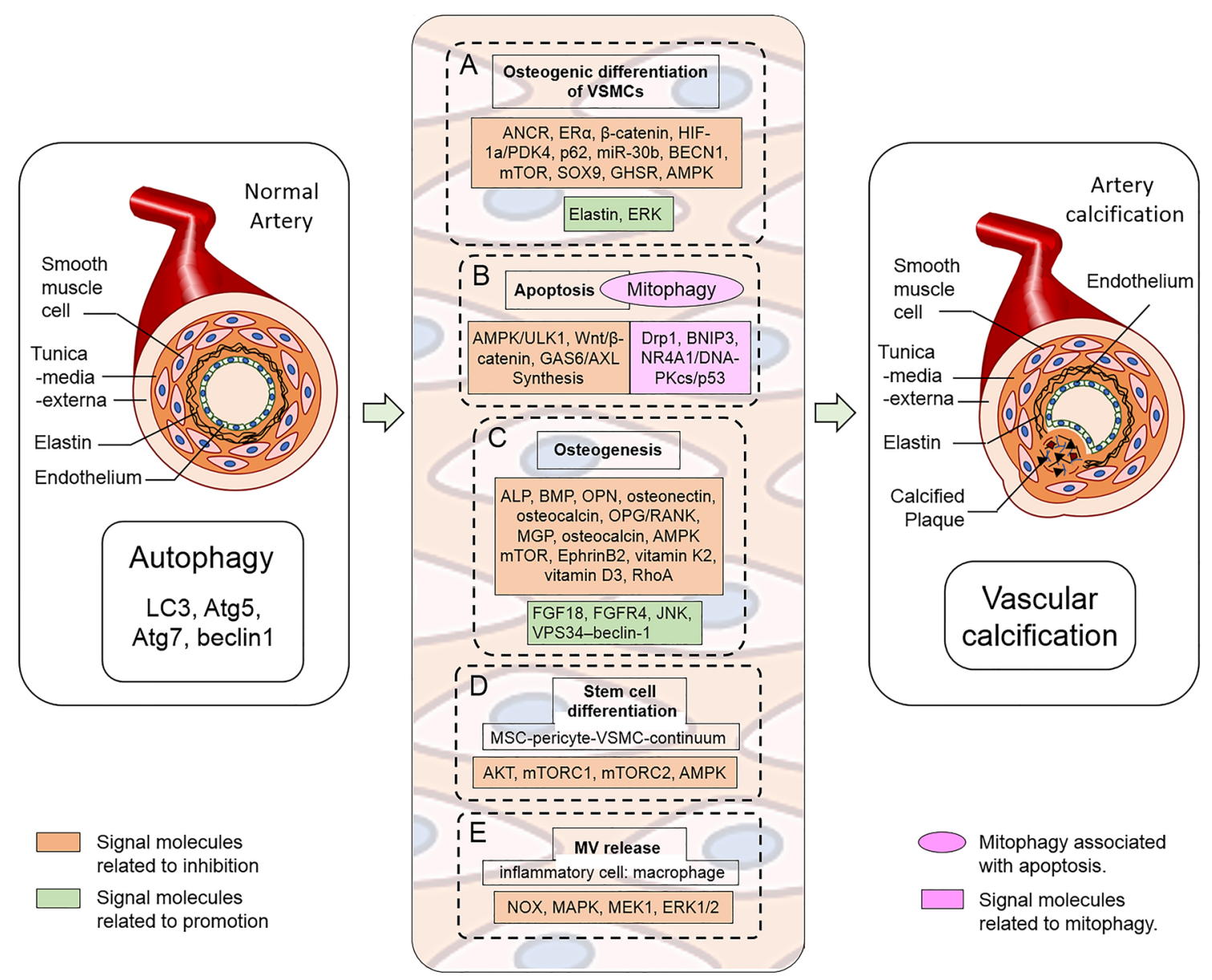

Fig. 1 Signaling molecules linking autophagy to vascular calcification. A Autophagy affects VC by interfering with the osteogenic differentiation of VSMCs. B Autophagy may affect VC by inhibiting apoptosis. C VC is a tightly cell-regulated pathological process that resembles osteogenesis. D The effect of autophagy regulation in stem cells on VC. E MV involved in autophagy regulation of VC 
presented protective effects against VC induced by AGEs [36].

Some miRNAs are implicated in proliferation, development, and function of VSMCs, and directly involved in pathological calcification [47]. miR-30b regulates the Runx2 expression and plays an important role in VC as a common feature in patients with CKD [48]. More studies have highlighted the central role of miR-30b in high Pi level-induced autophagy via the regulation of BECN1, which suggested miR-30b as possible target for the treatment of vascular diseases [49]. Li, et al.clarified that restoring miR-30b can promote autophagy while inhibiting VC by modulating mTOR signaling pathway in $\beta$-glycerophosphate induced VSMCs. miR-30b negative regulates SOX9 while restoring miR-30b in cell can increase the mitochondrial membrane potential (MMP) in $\beta$-glycerophosphate-induced VSMCs [37].

Hormonal ghrelin prevents osteoblastic transformation and mineralization of VSMCs mediated by GHSR/ERK signaling pathway [38]. Ghrelin application increases the expression of LC3 and beclin1 indicated autophagy, while 3-MA delays the ameliorative effect of ghrelin on VC. The protein levels of $\mathrm{p}$-AMPK are promoted by the hormonal treatment, and AMPK inhibitor, compound $C$ blocks the effect of ghrelin on VC and autophagy. In animal model, the hormone promotes autophagy in VC aorta and activates AMPK pathway meanwhile. Improved autophagy was detected following the activation of AMPK, which resulted in VC amelioration [50].

\section{Autophagy can promote the osteogenic differentiation of VSMCs within diverse circumstances}

The co-relationship between calcification and autophagy indicates that autophagy is one target for inhibition of VSMC calcification. Different from the inhibitory effect of autophagy on the osteogenic trans-differentiation of VSMCs, indoxyl sulfate stimulates the autophagy pathway through downregulating the expression of SET domain encompassing lysine methyltransferase 7/9. Subsequently, it can induce osteoblast differentiation and matrix mineralization of VSMCs [51] (Table 1).

Low dietary potassium can induce elevation of intracellular calcium, activate intracellular calcium signalingmediated CREB and autophagy, and further promote VSMC osteoblast differentiation and calcification [52]. The occurrence and development of VC symptom caused by autophagy were linked to autophagy-induced degradation of elastin [39].

Interestingly, in osteogenic differentiation of VSMCs, autophagy can play an opposite role within diverse circumstances. Besides the above, two independent teams approved that IV application of astragaloside effectively inhibit autophagy and mineralization in VSMCs, in which the inhibition is accomplished within the involvements of the ERK signaling pathway mediated by lncRNA H19 and DUSP5 [53] and mainly associated with mesenchymal stromal cells (MSCs) [25]. The biological circumstances on osteogenic differentiation left a critical challenge for drug design when developing anti-VC targeting autophagy pathway.

\section{Autophagy affects vascular calcification by inhibiting apoptosis}

It was proved that apoptotic cells can compose a nidus for the deposition of calcium-phosphate crystals [54]. The studies that apoptotic bodies form a nidus to nucleate apatite from dying VSMC [16] reflect the importance of $\mathrm{VC}$ promoted apoptosis, which indicated a possible mechanisms initiating the VSMC calcification process [55].

\section{Autophagy inhibits apoptosis and vascular calcification} Many works linked apoptosis and VSMC calcification in both human sample and animal models. For instance, massive apoptotic cell death found in both human and animal atherosclerotic plaques [56], suggests that apoptosis could promote calcification of providing matrix through the release of apoptotic bodies in nidus along with nucleation sites of VC. In calcification model of uremia, apoptosis is positively detected with calcification of VSMCs, which always occurs before calcification. The observation exhibited that in which apoptotic bodies were normally found to encompass with high concentrations of calcium by accumulating on extracellular matrix (ECM), and eventually leading to calcification [57].

In hyperphosphate-induced VC, inhibition of calcium aggradation can be attained by inhibiting apoptosis and potentiating autophagy and many hormonal molecules exhibits their critical roles [58-61]. Melatonin protected VSMCs against apoptosis and attenuated $\beta$-GP-induced VSMC calcification via autophagy stimulation associated to an AMPK/mTOR/ULK1 signaling pathway [59]. Bavachin suppresses apoptosis and calcification effects in HASMCs. Mechanism of the above hormonal effect is dependent on Atg7/mTOR-mediated autophagy pathway and suppression of $\mathrm{Wnt} / \beta$-catenin signaling [60]. Cozzolino group also claimed the related role of autophagy and apoptosis in the iron citrate preventing calcium deposition in high Pi-calcified VSMC associated with an iron-induced positive modulation of GAS6/AXL synthesis. They demonstrated that iron citrate arrests further high Pi-induced calcium deposition through an antiapoptotic action and induction of autophagy on established calcified VSMC [61].

While a different in vitro model was established to delay high phosphate-induced VC progression, the group 


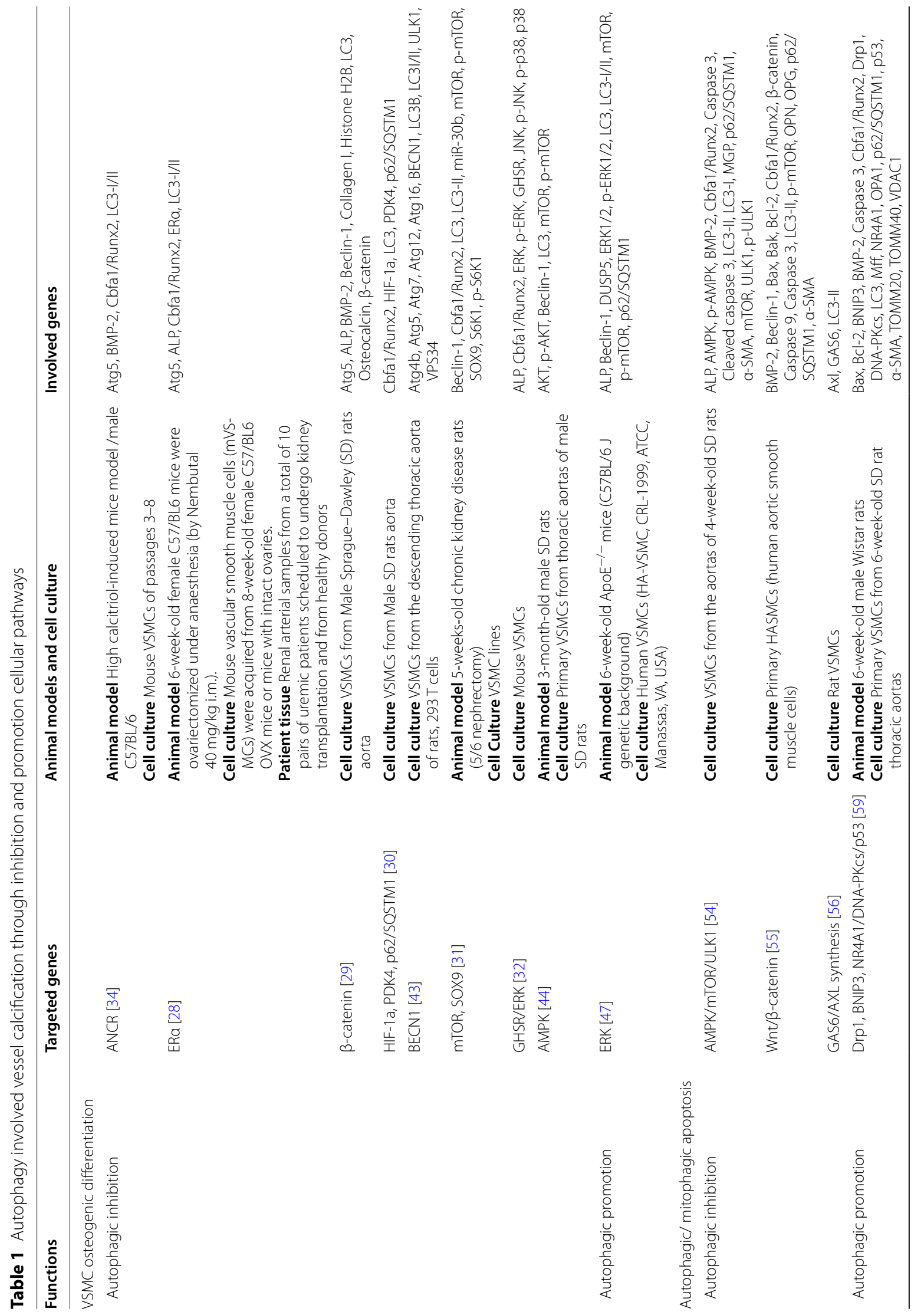




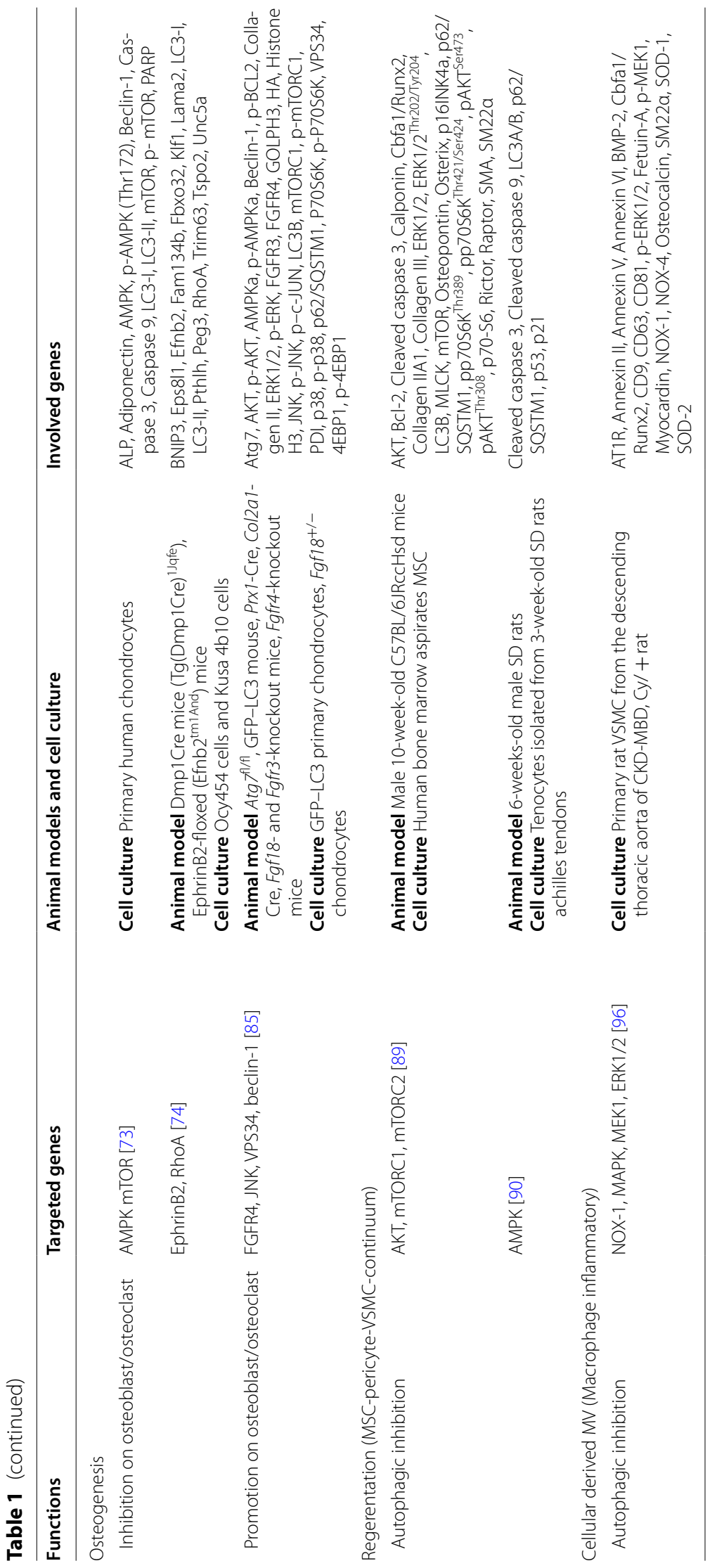


treated rat aortic VSMCs with high Pi in a repeated and short suspensions of high Pi treatment (intermittent suspension, IS). The treatment generates significant inhibition on high Pi calcification. Their data further approved that the inhibition on apoptosis is carried out through the preservation of AXL protein levels [62] and enhanced autophagy plays a protective role in arterial calcification through inhibiting apoptosis.

\section{Mitophagy partially reverse mitochondrial disorder of vascular calcification}

After mitochondrial toxicity is induced, the damaged mitochondria will be wrapped in a double-layer membrane structure to form autophagosomes, which are further degraded by lysosomes, otherwise the intrinsic apoptotic pathways will be activated. Its on-site accumulation promotes crystallization as nucleation of calcium phosphate crystals for further VC plaques [63]. Other data demonstrated that lactate impaired mitochondrial function inducing oxidative stress and apoptosis during VSMC calcification.

The Drp1-related mitochondrial fission promoted by lactate through NR4A1 upregulation, while NR4A1 suppressed the autophagic flux and BNIP3-mediated mitophagy, which were by $\mathrm{p} 53$ regulated phosphorylation. The regulation of Drp1 and BNIP3 is further related to the NR4A1/DNA-PKcs/p53 pathway in the pathological plaques [64]. BNIP3-mediated mitophagy could partially reverse mitochondrial disorder, excessive oxidative stress and enhanced apoptosis, which plays a protective role against VSMC calcification in the presence of lactate [65]. This phenomenon suggests that, to some extent, autophagy/mitophagy can avert the activation of apoptotic pathways by the removal of damaged mitochondria [66].

As two critical catabolic processes that assist preserve cell and tissue homeostasis [67, 68], autophagy and apoptosis are highly related in deciding cell fate. Apoptosis stringently related to autophagy could be considered the result of the failure of autophagy to re-establish a physiological balance for the cells involving in survival. Autophagy can promote cell survival, but under certain conditions, autophagy also protected cells from necrosis via promoting apoptosis. The autophagy played a role in either promoting apoptosis or inhibiting apoptosis [68]. Therefore, the precarious issue is how to determine the range of moderate and appropriate mitophagy for VC.

\section{VC associated osteogenic resembling and cellular pathological autophagy}

The normal distribution where calcium is mineralized in the human body are bones and teeth meanwhile it becomes $\mathrm{VC}$ when calcium is excessively deposited on the blood vessel wall [28]. In the process of $\mathrm{VC}$, the cells within vascular wall are transformed into an osteoblastlike phenotype, and begin to synthesize and secrete a variety of proteins related to bone formation, such as ALP, bone morphogenetic protein (BMP), osteopontin (OPN), osteonectin, osteocalcin, etc. [69]. Calcium nodules are formed in the extracellular matrix or cytoplasm of these cells, which are tightly associated with non-bone osteogenesis or autophagy related mineral resembling [70].

\section{Vascular calcification and osteoporosis}

While VC patients with high risk are often accompanied with osteoporosis, Matrix Gla protein (MGP) and osteocalcin are important factors for their regulation. The normal calcium balance in the human body guarantees the amount of calcium required in bones and teeth, but not abnormal calcium deposition in other locations such as blood vessels and internal organs [71]. When this calcium associated metabolism is disturbed, it will lead to a series of diseases, such as osteoporosis due to excessive loss of calcium in the bones, and dominant gain of calcium on the blood vessel wall.

VC often occurs simultaneously with low bone mineral density or poor bone turnover [72]. In general consideration, the balance and metabolism of calcium are closely related to vitamin K2, vitamin D3, MGP and osteocalcin [73]. The study of $\mathrm{VC}$ mechanism often involves changes in the expression of proteins related to bone development, such as OPG/RANK, OPN, MGP, BMP, etc. [69], in which the proteins plus blood calcium are cellular and mechanically resembled bone tissue architecture during osteogenesis. This bone-like structure formation is based on the structure and scaffold of blood vessels, and depending on osteoblasts differentiated from angiogenic pericytes or blood-borne mesenchymal cells surrounding the vasculature [74]. Up to date, many factors regulating bone mineralization are proved in calcified plaques $[75$, 76].

\section{Autophagy exhibits variable effects in the metabolism of bone tissue and vessel}

Property of autophagic recycling damaged organelles is highly related to bone metabolism during the dynamic synthesis and degradation process in bone [77]. Autophagy can display variable effects in the calcification of chondrocytes/osteocytes. Then, AdipoRon can activate autophagy of Osteoarthritis (OA) chondrocytes through the AMPK mTOR pathway, and as well improve autophagy contribution to suppress calcification in OA chondrocytes [78].

Using osteocyte differentiation approach, Vrahnas and colleagues collected data within in vitro system on 
murine stromal cell lines, Ocy454 cells and Kusa 4b10 cells compared to Dmp1Cre mice $\left(\mathrm{Tg}(\mathrm{Dmp} 1 \mathrm{Cre})^{1 \mathrm{Jqfe}}\right)$ and EphrinB2-floxed (Efnb2 ${ }^{\text {tm1And }}$ ) mice. The data exhibited that significant mineral deposition in Dmp1 Cre.Efnb $2^{\mathrm{f} / \mathrm{f}}$ bone along with massive increase of autophagosomes [79] and EphrinB2 deletion in osteocytes generated defected mice with brittle bones. Their result approved that Osteocytic EphrinB2 could limits autophagy through RhoA, which could be responsible for limiting mineral accumulation and carbonate substitution within the bioapatite matrix and restraining collagen fiber compaction [79]. Subsequently, further investigations unveiled that EphrinB2 deficiency in bones dysregulated many genes including Fam134b [80], Fbxo32 [81], Lama2 [82], Bnip3 [83], Peg3 [84], Eps8l1 [85], Klf1 [86], Tspo2 [87], and Unc5a [88], which is specifically related to a series of autophagy processes, including mitophagy and ER-phagy.

Recently, a study claimed that autophagy plays a critical role in promoting vascular calcification within osteoblast differentiation and mineralization using vitamin K2-induced MC3T3 E1 cells [89]. During post-natal bone development, autophagy is induced in growth-plate chondrocytes during post-natal bone development via regulating the secretion of type II collagen (Col2). When FGFR4 and JNK-dependent activation, the autophagy initiated complex VPS34 and beclin-1 [90]. Therefore, on compression on how autophagy regulating $\mathrm{VC}$, further investigations can plagiarize the above information from bone formation [80-88].

\section{The effect of autophagy regulation in stem cells on vascular calcification}

Because both VSMCs and osteoblasts are mesenchymal originated, many works focus on the mechanism of $\mathrm{VC}$ on the correlation with stem cells. Interestingly, as MSCs have a dual role as progenitors to osteoblasts and pericytes further to develop to VSMC, some studies found that cells with MSC phenotype in the adventitia of arteries are the major source of osteoblast-like cells in intimal and medial calcification [29]. The uremic milieu causes osteoblastic differentiation of MSC and calcification [91], indicating loss of vascular progenitor properties.

Recently, Carracedo and his colleagues discovered that initiated autophagy in calcific aortic valve stenosis (CAVS) confers protection of valvular interstitial cells (VICs). Their data suggest that the upregulation of autophagy observed in the calcified tissue of these valves serves as a compensatory and pro-survival mechanism to protect valves from calcification [92]. Their results are also supported by another result that VIC autophagy could prevent calcification via pro-osteogenic signaling [93]. Hegner and colleagues discovered that mTORC1 and mTORC2 pathways show different regulatory roles in cell fate during the osteoblastic differentiation from MSCs. Furthermore, other studies demonstrated that blockade of autophagy can exacerbate calcification of differentiated MSC. Inhibition of AKT signaling or genetic depletion of mTORC2 abrogate the protective effect of rapamycin on MSC calcification. And enhanced mTORC2 signaling is sufficient in this protection effect from MSC against calcification [94]. Autophagy could be attributed a key role in the transition from undifferentiated MSC to osteoblast-like calcifying cells.

In a recent report, a study shows that, in tendonderived stem cells (TDSCs), pioglitazone increased the ratio of $\mathrm{LC} 3 \mathrm{~B} / \mathrm{LC} 3 \mathrm{~A}$ and decreased that of $\mathrm{P} 62$ expression, and performed as an agonist to promote autophagy via modulation of the AMPK/mTOR pathway. Pioglitazone treatment can induce autophagy flux in AGEs-treated TDSCs, which possesses anti-apoptosis, anti-senescence, and anti-ossification effects [95]. Based on the discussion above, targeting on differentiated progenitor cells such as VSMC and osteoblast-like cells could maintain and resort the endogenously physiological MSC function. Enabling protective cell fate patterns in the MSC-pericyte-VSMC-continuum could be an innovative approach for treatment of $\mathrm{VC}$.

\section{MV involved in autophagy regulation of vascular calcification}

As an effective approach based on recent investigation, MV can be transmitted among co-cultured cells through endocytosis and induced cell-cell communication. When extracellular MV exosomes containing low fetuin-A content were added to recipient VSMC, the calcification was increased upon these cells. The increase in calcium induced by cellular derived MV is partly attributable to the activation of NOX and MAPK (MEK1 and Erk1/2) signaling pathway [96].

MVs formed from VSMCs and macrophages under atherosclerotic conditions mainly, are calcified and released into the collagen-rich matrix within the intima of vessel $[19,97]$. Macrophages indirectly promote mineral formation by producing the inflammatory cytokines while lipid oxidation products promote vascular cell mineralization. $\mathrm{Xu}$, et al emphasized that autophagy would be an endogenous protective mechanism counteracting $\mathrm{VC}$ under hyperphosphatemia. The autophagy inhibition leads to increased MV release rather than cell apoptosis, and the inhibition promoted Pi-induced MV release and increased ALP activity may be the cause of calcification [31]. Other study on the calcification of aortic leaflets claimed that autophagy resulted in the release of MVs in early degenerative aortic valves, which attract 
Table 2 Autophagy related proteins in human and their functions in vascular calcification

\begin{tabular}{|c|c|c|c|c|c|c|c|c|}
\hline$\#$ & $\begin{array}{l}\text { Autophagy } \\
\text { proteins involved }\end{array}$ & Functions in VC process & PubMed ID & $\begin{array}{l}\text { Chromosome } \\
\text { location/band }\end{array}$ & $\begin{array}{l}\text { Transcript } \\
\text { (bp) }\end{array}$ & CDS (bp) & $\begin{array}{l}\text { Peptides } \\
\text { (AA) }\end{array}$ & References \\
\hline \multirow[t]{2}{*}{1} & $\begin{array}{l}\text { LC3-I transcript } \\
\quad \text { variant } 1\end{array}$ & \multirow{2}{*}{$\begin{array}{l}\text { Cysteine protease cleaved } \\
\text { LC3 I from LC3 inhibits } \\
\text { osteogenic differentiation } \\
\text { of VSMCs }\end{array}$} & NM_032514 & \multirow{2}{*}{$\begin{array}{l}\text { Chromo- } \\
\text { some 20: } \\
\text { 34,546,854- } \\
\text { 34,560,345 } \\
\text { forward } \\
\text { strand; } \\
\text { 20q11.22 }\end{array}$} & 964 & 366 & 121 & Peng et al. [28] \\
\hline & $\begin{array}{l}\text { LC3-I transcript } \\
\text { variant } 2\end{array}$ & & NM_181509 & & 971 & 378 & 125 & $\begin{array}{r}\text { Zhang et al. [34]; } \\
\text { Song et al. [47]; } \\
\text { Xu et al. [90] }\end{array}$ \\
\hline 2 & $\begin{array}{l}\text { Atg5(Autophagy } \\
\text { related 5) }\end{array}$ & $\begin{array}{l}\text { Knocking down Atg5 } \\
\text { expression significantly } \\
\text { upregulates } \beta \text {-GP-induced } \\
\text { Runx2 expression and ALP } \\
\text { activity along inhibition of } \\
\text { osteogenic differentiation } \\
\text { of VSMCs }\end{array}$ & JQ924061.1 & $\begin{array}{l}\text { Chromo- } \\
\text { some 6: } \\
\text { 106,045,423- } \\
\text { 106,325,791 } \\
\text { reverse } \\
\text { strand; 6q21 }\end{array}$ & 828 & 828 & 275 & $\begin{array}{r}\text { Dai et al. [25]; } \\
\text { Zhang et al. [34] }\end{array}$ \\
\hline 3 & LC3-II & $\begin{array}{l}\text { Along with enhancing } \\
\text { autophagic flux, LC3-II } \\
\text { augmenter the number of } \\
\text { autophagosome by reduc- } \\
\text { ing the RUNX2 expression }\end{array}$ & NM_022818 & $\begin{array}{l}\text { Chromo- } \\
\text { some 16: } \\
87,383,953- \\
87,404,779 \\
\text { forward } \\
\text { strand; } \\
\text { 16q24.2 }\end{array}$ & 2147 & 378 & 125 & $\begin{array}{l}\text { Peng et al. [28] } \\
\text { Yang et al. [30] } \\
\text { Song et al. [47]; } \\
\text { Xu et al. [90] }\end{array}$ \\
\hline 4 & p62 (SQSTM1) & $\begin{array}{l}\text { By reducing the RUNX2 } \\
\text { expression, p62 augmenter } \\
\text { the number of autophago- } \\
\text { some }\end{array}$ & M88108 & $\begin{array}{l}\text { Chromo- } \\
\text { some 5: } \\
\text { 179,806,398- } \\
\text { 179,838,078 } \\
\text { forward } \\
\text { strand; } \\
\text { 5q35.3 }\end{array}$ & 2685 & 1332 & 443 & Yang et al. [30] \\
\hline \multirow[t]{3}{*}{5} & \multirow{3}{*}{$\begin{array}{l}\text { Beclin1 transcript } \\
\text { variant } 1\end{array}$} & \multirow{3}{*}{$\begin{array}{l}\text { As an up-regulator of } \\
\text { autophagic pathway, bec- } \\
\text { lin1 decreases expression of } \\
\text { Runx2 and Msx2 }\end{array}$} & NM_003766 & \multirow{3}{*}{$\begin{array}{l}\text { Chromo- } \\
\text { some 17: } \\
\text { 42,810,134- } \\
\text { 42,833,350 } \\
\text { reverse } \\
\text { strand; } \\
\text { 17q21.31 }\end{array}$} & 2131 & 1353 & 450 & Xu et al. [31] \\
\hline & & & NM_001313998 & & 2109 & 1353 & 450 & Wang et al. [43] \\
\hline & & & NM_001313999 & & 1840 & 1068 & 355 & \\
\hline \multirow[t]{3}{*}{6} & $\begin{array}{l}\text { Atg7 transcript } \\
\text { variant } 4\end{array}$ & \multirow{3}{*}{$\begin{array}{l}\text { As an upstream autophagy- } \\
\text { related gene of LC3, Atg7 } \\
\text { promotes the conversion of } \\
\text { LC3-I to LC3-II and preven- } \\
\text { tion of calcification }\end{array}$} & NM_001349232 & \multirow{3}{*}{$\begin{array}{l}\text { Chromo- } \\
\text { some 3: } \\
\text { 11,272,309- } \\
\text { 11,557,665 } \\
\text { forward } \\
\text { strand; } \\
\text { 3p25.3 }\end{array}$} & 5333 & 2112 & 703 & He et al. [58] \\
\hline & $\begin{array}{l}\text { Atg7 transcript } \\
\text { variant } 5\end{array}$ & & NM_001349233 & & 5087 & 2112 & 703 & \\
\hline & $\begin{array}{l}\text { Atg7 transcript } \\
\text { variant } 7\end{array}$ & & NM_001349235 & & 5224 & 2112 & 703 & \\
\hline \multirow[t]{2}{*}{7} & $\begin{array}{l}\text { VPS34 transcript } \\
\text { variant } 1\end{array}$ & \multirow{2}{*}{$\begin{array}{l}\text { Forming VPS34-beclin-1 com- } \\
\text { plex for autophagy initiation } \\
\text { and promoting vascular } \\
\text { calcification }\end{array}$} & NM_002647 & \multirow{2}{*}{$\begin{array}{l}\text { Chromo- } \\
\text { some 18: } \\
\text { 41,955,234- } \\
\text { 42,087,830 } \\
\text { forward } \\
\text { strand; } \\
\text { 18q12.3 }\end{array}$} & 9415 & 2664 & 887 & \multirow[t]{2}{*}{ Cinque et al. [85] } \\
\hline & $\begin{array}{l}\text { VPS34 transcript } \\
\text { variant } 2\end{array}$ & & NM_001308020 & & 9226 & 2475 & 824 & \\
\hline
\end{tabular}

inflammatory cells and triggered calcification of the valve $[98,99]$.

Depending on various induction signals, the origin and selected content in the MVs of autophagy promoted VSMC exocytosis are different [31, 32], and MVs are considered the first nidus for mineralization in the vessel wall [30]. Therefore, as an effective hydroxyapatite mediator, the mechanism of MV autophagy release in the initiation and development of VC needs more detailed research. 


\section{Current clinical trial involved with autophagy related treatment for VC}

Autophagy related treatment have been used for halting many cancer development involved with autophagic pathways including in both animal models and human samples [100-103]. Strong potential drugs against diverse tumors were designed and applied as anti-cancer therapy. Autophagy-targeting drugs such as autophagy inhibitors Choloroquine and Bafilomycin A1 targeting on endosomal acidification, and 3-Methyladenine and LY294002 targeting PI3K pathway currently approved for use in the treatment of solid and non-solid malignancies [100]. However, up to date, only one drug SNF472 against autophagy recently were used on Phase 2 treatment for treatment against cardiovascular calcification in patients with actual strong positive results [103, 104].

As a derivative of phytic acid, SNF472 (hexasodium salt of phytate) play a critical role as a potential treatment for Alzheimer's disease targeting on autophagy- associated proteins (beclin-1 and LC3B) [105]. Currently, using SNF472 as a calcification inhibitor, a clinical Phase II CaLIPSO trial (EudraCT 2016-002834-59) for the treatment of cardiovascular calcification is completed. Based on double-blind and placebo-controlled Phase II trial, computed tomography scan unveiled that, in randomized three groups including SNF472 $300 \mathrm{mg}(\mathrm{n}=92) / \mathrm{SNF} 472600 \mathrm{mg}$ $(\mathrm{n}=91) /$ or placebo control $(\mathrm{n}=91)$, two SNF472 dosages significantly slowed down of both the accumulation of coronary artery calcium and the development of aortic valve calcification $[103,104]$. This favorable data highlights strong possibility to develop more practical and high efficient approach with other drugs targeting on the pathway of the molecular mechanism of autophagy in $\mathrm{VC}$ associated cardiovascular disorders.

With the above promising results, it would be rational to accomplish more clinical trials associated with autophagic proteins (Table 2) based on massive positive data obtained animal models. Providentially, along with endosomal acidification targeted and PI3K pathway targeted autophagy inhibitors, MAPK pathway associated inhibitors including SB202190 and SB203580 also be available for diverse $\mathrm{VC}$ related trials. The advantage should be employed in which many autophagy inhibitors are FDA approved drugs that can be used in other diseases [100-102].

\section{Conclusion and perspective}

The maintenance of the normal structure of blood vessels and the regulation of its functions are critical for circulation system which is tightly related to autophagy. Within a certain criteria, autophagy activation as a protective affection on VSMCs can promote cell survival, lead to enhanced cell proliferation, migration, and extracellular matrix secretion, and reduce calcification. Removing cell debris such as misfolded proteins and dysfunctional organelles that can cause senescence and apoptosis, autophagy plays an important role in maintaining the adaptability of juvenile cells [95]. Reversely, when autophagy is inhibited, lack of autophagy leads to accumulation of harmful substances in cells, cell aging, changes in vascular structure, vasomotor function becomes abnormal, and the increasing incidence of VC. When autophagy is beyond the scope of its beneficial effects and/or over-activated, cell and organelle damage within VSMCs could lead to the vascular calcification accompanying with triggering cell death, and further accelerating the occurrence of VC. Autophagy plays an intricate and often distinct role under various pathological conditions.

The effects of autophagy on VC appears to be complicated, which depend on degree of autophagy associated with disease status, location, and the surrounding microenvironment. Autophagy activation in the presence of acute pathological damage is generally considered to be protective, resulting in degradation of dysfunctional cellular components and maintenance of cell homeostasis. Reversely, some chronic diseases induce sustained autophagy which may be detrimental, since defective autophagy can activate the apoptotic pathway, damage important organelles and cause cell apoptosis. In order to develop effective and unique approaches to slow down or eliminate VC targeting on VC-related autophagy, the functional and regulatory genes in osteogenesis including the bone formation such as Fam134b, Klf1 and Bnip3, and the MSCs differentiation such as ALP, Runx2 and BMPs could be efficient candidates. The more intensive investigation on precise chick-point between these beneficial function and apoptotic death occurred on vessel wall, would be critical in further study in this field.

\section{Abbreviations}

AKT/PKB: Protein kinase B; AMPK: AMP-activated protein kinase; Atg: Autophagy-related gene; ANCR: Anti-differentiation noncoding RNA; AGEs: Advanced glycation end products; ALP: Alkaline phosphatase; apoE: Apolipoprotein E; a-SMA: Alpha smooth muscle actin; BMP: Bone morphogenetic protein; BSA: Bovine serum albumin; BNIP3: BCL2/adenovirus E1B 19 kDa protein-interacting protein 3; $\beta$-GP: $\beta$-Glycerophosphate; CREB: CAMP response element-binding protein; Col2: Type II collagen; CAVS: Calcific aortic valve stenosis; CKD: Chronic kidney disease; DUSP5: Dual specificity protein phosphatase 5; Drp1: Dynamin-related protein 1; DNA-PKcs: DNA-dependent protein kinase, catalytic subunit; ERa: Oestrogen receptor alpha; ERß: Oestrogen receptor beta; ER-phagy: Microautophagic degradation of the ER; ECM: Extracellular matrix; ERK1/2: Extracellular signal-regulated kinases1/2; FGF23: Fibroblast Growth Factor 23; FGF18: Fibroblast growth factor 18; FGFR4: Fibroblast growth factor receptor 4; GFP: Green fluorescent protein; GAS6: Growth arrest-specific 6; GHSR (ghrelin receptor): Growth hormone secretagogue receptor; HIF-1a: Hypoxia-inducible factor 1-alpha; HASMCs: Human Aortic Smooth Muscle Cells; IS: Intermittent suspension; JNK-dependent: C-Jun $\mathrm{N}$-terminal kinases; LC3: Microtubule-associated protein 1A/1B-light chain 3; 
LAMP-1: Lysosomal-associated membrane protein 1; IncRNA H19: Long noncoding RNAs; MAPK: Mitogen-activated protein kinase; mTOR: Mammalian target of rapamycin; mRFP: Monomeric red fluorescent proteins; Mitophagy: Degradation of mitochondria; MScs: Mesenchymal stromal cells; mTORC1: Mammalian target of rapamycin complex 1; mTORC2: Mammalian target of rapamycin complex 2; MV: Matrix Vesicle; MMP: Mitochondrial membrane potential; MGP: Matrix Gla protein; NR4A1: Nuclear receptor subfamily 4 group A member 1; NOX: NADPH oxidase; OPN: Osteopontin; OCN: Osteocalcin; OPG: Osteoprotegerin; OA: Osteoarthriti; PI3K: Phosphoinositide 3-kinases; p53: Tumor protein p53; PDK4: Pyruvate dehydrogenase kinase 4; PPi: Pyrophosphoric acid; p62/SQSTM1: Sequestosome 1; ULK: Unc-51-like kinase 1; p53: Tumor protein p53; RANK: Receptor activator of nuclear factor $\mathrm{KB}$; RhoA: Ras homolog family member A; Runx2: Runt-related transcription factor 2; SM22a: Smooth muscle 22 alpha; TGF- $\beta 1$ : Transforming growth factor beta 1; TEM: Transmission electron microscopy; TDSCs: Tendon-derived stem cells; VC: Vascular calcification; VSMCs: Vascular smooth muscle cells; VICs: Valvular interstitial cells; 3-MA: 3-Methyladenine.

\section{Acknowledgements}

Not applicable.

\section{Authors' contributions}

$X Z$ and HLC conceived, $X Z$, SNX and STY wrote the manuscript, XJL, LX, HJL, $C X H, W Q, D Z$, and $X Y S$ collected and analyzed references. $X H X$ provided the recent information and analysis on the clinical trial in the manuscript. EM, HLC and XHX edited and finalized the manuscript. All authors read and approved the final manuscript.

\section{Funding}

This work was supported by the Key Program of Shaanxi Provincial Education Department (No. 20JS138 to XZ); the National Natural Science Foundation of China (No. U1932130 to H-LC, No. 31700699 to WQ); the Natural Science Basic Research Program Youth Project of Shaanxi Provincial Science and Technology Department (No. 2020JQ-885 to XZ); the Program of Shaanxi Administration of Traditional Chinese Medicine (No. 2019-ZZ-ZY009 to $\mathrm{H}-\mathrm{LC}$ ); the Key Program of Weiyang District Bureau of Science, Technology and Industry Information Technology (No. 201928 to H-LC); College Student Innovation Training Program of Xi'an Medical University (No. 121520012/ S202011840012/20201 1840012to S-TY), Doctorial Program from Xi'an Medical University (No. 2020DOC28 to XZ); X-HX is partially supported through NSFC Grant No. \#31771377/31571273/31371256 and Ministry of Education Central Universities Research Fund GK201301001/201701005.

\section{Availability of data and materials}

Data and materials are available upon request to corresponding author.

\section{Declarations}

\section{Ethics approval and consent to participate}

Not applicable.

\section{Consent for publication}

Not applicable.

\section{Competing interests}

The authors declare that they have no competing interests.

\section{Author details \\ 'Shaanxi Key Laboratory of Ischemic Cardiovascular Disease, Shaanxi Key Laboratory of Brain Disorders, Institute of Basic \& Translational Medicine, Xi'an Medical University, Xi'an 710021, Shaanxi, China. ${ }^{2}$ Department of Cardiology, The First Affiliated Hospital, Xi'an Medical University, Xi'an 710021, Shaanxi, China. ${ }^{3}$ Laboratory of Cell Biology, Genetics and Developmental Biology, Shaanxi Normal University College of Life Sciences University Hospital Medical Center, Xi'an 710062, Shaanxi, China. ${ }^{4}$ College of Pharmacy, Shaanxi University of Chinese Medicine, Xianyang 712046, Shaanxi, China. ${ }^{5}$ Johns Hopkins Uni- versity School of Medicine, Baltimore, MD 21205, USA.}

Received: 12 October 2020 Accepted: 27 June 2021

Published online: 16 August 2021

\section{References}

1. Yahagi K, Kolodgie FD, Lutter C, Mori H, Romero ME, Finn AV, Virmani R. Pathology of human coronary and carotid artery atherosclerosis and vascular calcification in diabetes mellitus. Arterioscler Thromb Vasc Biol. 2017;37(2):191-204. https://doi.org/10.1161/atvbaha.116.306256.

2. Vervloet M, Cozzolino M. Vascular calcification in chronic kidney disease: different bricks in the wall? Kidney Int. 2017;91(4):808-17. https://doi. org/10.1016/j.kint.2016.09.024.

3. Lee SJ, Lee IK, Jeon JH. Vascular calcification - new insights into its mechanism. Int J Mol Sci. 2020;21(8):2685. https://doi.org/10.3390/ijms2 1082685.

4. Tesauro M, Mauriello A, Rovella V, Annicchiarico-Petruzzelli M, Cardillo C, Melino G, Di Daniele N. Arterial ageing: from endothelial dysfunction to vascular calcification. J Intern Med. 2017;281(5):471-82. https://doi.org/ 10.1111/joim.12605.

5. Ohtake T, Kobayashi S. Impact of vascular calcification on cardiovascular mortality in hemodialysis patients: clinical significance, mechanisms and possible strategies for treatment. Ren Replace Ther. 2017;3(1):1-11. https://doi.org/10.1186/s41100-017-0094-y.

6. Demer LL, Tintut Y. Inflammatory, metabolic, and genetic mechanisms of vascular calcification. Arterioscler Thromb Vasc Biol. 2014;34(4):715-23. https://doi.org/10.1161/atvbaha.113.302070.

7. Onorati AV, Dyczynski M, Ojha R, Amaravadi RK. Targeting autophagy in cancer. Cancer. 2018;124(16):3307-18. https://doi.org/10.1002/cncr. 31335.

8. Hughes WE, Beyer AM, Gutterman DD. Vascular autophagy in health and disease. Basic Res Cardiol. 2020;115(4):41. https://doi.org/10.1007/ s00395-020-0802-6.

9. Saha S, Panigrahi DP, Patil S, Bhutia SK. Autophagy in health and disease: A comprehensive review. Biomed Pharmacother. 2018;104:485-95. https://doi.org/10.1016/j.biopha.2018.05.007.

10. Kroemer G, Levine B. Autophagic cell death: the story of a misnomer. Nat Rev Mol Cell Biol. 2008;9(12):1004-10. https://doi.org/10.1038/nrm2529.

11. Wang S, Deng Z, Ma Y, Jin J, Qi F, Li S, Liu C, Lyu FJ, Zheng Q. The role of autophagy and mitophagy in bone metabolic disorders. Int J Biol Sci. 2020;16(14):2675-91. https://doi.org/10.7150/ijbs.46627.

12. Colella B, Faienza F, Carinci M, D'Alessandro G, Catalano M, Santoro A, Cecconi F, Limatola C, Di Bartolomeo S. Autophagy induction impairs Wnt/ $\beta$-catenin signalling through $\beta$-catenin relocalisation in glioblastoma cells. Cell Signal. 2019;53:357-64. https://doi.org/10.1016/j.cellsig. 2018.10.017.

13. Bravo-San Pedro JM, Kroemer G, Galluzzi L. Autophagy and mitophagy in cardiovascular disease. Circ Res. 2017;120(11):1812-24. https://doi. org/10.1161/circresaha.117.311082.

14. Abdellatif M, Sedej S, Carmona-Gutierrez D, Madeo F, Kroemer G. Autophagy in cardiovascular aging. Circ Res. 2018;123(7):803-24. https:// doi.org/10.1161/circresaha.118.312208.

15. Durham AL, Speer MY, Scatena M, Giachelli CM, Shanahan CM. Role of smooth muscle cells in vascular calcification: implications in atherosclerosis and arterial stiffness. Cardiovasc Res. 2018;114(4):590-600. https:// doi.org/10.1093/cvr/cvy010.

16. Proudfoot D, Skepper JN, Hegyi L, Bennett MR, Shanahan CM, Weissberg PL. Apoptosis regulates human vascular calcification in vitro: evidence for initiation of vascular calcification by apoptotic bodies. Circ Res. 2000;87(11):1055-62. https://doi.org/10.1161/01.res.87.11.1055.

17. Viegas C, Araújo N, Marreiros C, Simes D. The interplay between mineral metabolism, vascular calcification and inflammation in Chronic Kidney Disease (CKD): challenging old concepts with new facts. Aging (Albany NY). 2019;11(12):4274-99. https://doi.org/10.18632/aging.102046.

18. Yamada S, Giachelli CM. Vascular calcification in CKD-MBD: roles for phosphate, FGF23, and Klotho. Bone. 2017;100:87-93. https://doi.org/10. 1016/j.bone.2016.11.012.

19. Kapustin AN, Chatrou ML, Drozdov I, Zheng Y, Davidson SM, Soong D, Furmanik M, Sanchis P, De Rosales RT, Alvarez-Hernandez D, et al. Vascular smooth muscle cell calcification is mediated by regulated exosome secretion. Circ Res. 2015;116(8):1312-23. https://doi.org/10.1161/circr esaha.116.305012.

20. Wei R, Enaka M, Muragaki Y. Activation of KEAP1/NRF2/P62 signaling alleviates high phosphate-induced calcification of vascular smooth muscle cells by suppressing reactive oxygen species production. Sci Rep. 2019;9(1):10366. https://doi.org/10.1038/s41598-019-46824-2. 
21. Xu MM, Seas A, Kiyani M, Ji KSY, Bell HN. A temporal examination of calcium signaling in cancer- from tumorigenesis, to immune evasion, and metastasis. Cell Biosci. 2018;8:25. https://doi.org/10.1186/ s13578-018-0223-5.

22. Wang L, Xu MM, Li Z, Shi M, Zhou X, Jiang X, Bryant J, Balk S, Ma J, Isaacs W, Xu H. Calcium and CaSR/IP3R in prostate cancer development. Cell Biosci. 2018;8:16. https://doi.org/10.1186/s13578-018-0217-3.

23. Zhou X, Li Z, Wang Z, Chen E, Wang J, Chen F, Jones O, Tan T, Chen S, Xu $X$, et al. Syncytium calcium signaling and macrophage function in the heart. Cell Biosci. 2018;8:24. https://doi.org/10.1186/s13578-018-0222-6.

24. Xuehong Xu, Balk SP, Isaacs WB, Ma J. Calcium signaling: an underlying link between cardiac disease and carcinogenesis. Cell Biosci. 2018;8:39. https://doi.org/10.1186/s13578-018-0236-0.

25. Pantovic A, Krstic A, Janjetovic K, Kocic J, Harhaji-Trajkovic L, Bugarski D, Trajkovic V. Coordinated time-dependent modulation of AMPK/Akt/ mTOR signaling and autophagy controls osteogenic differentiation of human mesenchymal stem cells. Bone. 2013;52(1):524-31. https://doi. org/10.1016/j.bone.2012.10.024.

26. Lanzer P, Boehm M, Sorribas V, Thiriet M, Janzen J, Zeller T, St Hilaire C, Shanahan C. Medial vascular calcification revisited: review and perspectives. Eur Heart J. 2014;35(23):1515-25. https://doi.org/10.1093/eurhe artj/ehu163.

27. Johnson RC, Leopold JA, Loscalzo J. Vascular calcification: pathobiological mechanisms and clinical. Circ Res. 2006;99(10):1044-59. https://doi. org/10.1161/01.res.0000249379.55535.21. [published correction appears in Circ Res. 2009 Sep 11;105(6):e8].

28. Caffarelli C, Montagnani A, Nuti R, Gonnelli S. Bisphosphonates, atherosclerosis and vascular calcification: update and systematic review of clinical studies. Clin Interv Aging. 2017;12:1819-28. https://doi.org/10. 2147/cia.s138002.

29. Kramann R, Goettsch C, Wongboonsin J, Iwata H, Schneider RK, Kuppe C, Kaesler N, Chang-Panesso M, Machado FG, Gratwohl S, et al. Adventitial MSC-like cells are progenitors of vascular smooth muscle cells and drive vascular calcification in chronic kidney disease. Cell Stem Cell. 2016;19(5):628-42. https://doi.org/10.1016/j.stem.2016.08.001.

30. Shanahan CM. Autophagy and matrix vesicles: new partners in vascular calcification. Kidney Int. 2013;83(6):984-6. https://doi.org/10.1038/ki. 2013.75.

31. Dai XY, Zhao MM, Cai Y, Guan QC, Zhao Y, Guan Y, Kong W, Zhu WG, Xu MJ, Wang X. Phosphate-induced autophagy counteracts vascular calcification by reducing matrix vesicle release. Kidney Int. 2013;83(6):1042-51. https://doi.org/10.1038/ki.2012.482.

32. Lee K, Kim H, Jeong D. Microtubule stabilization attenuates vascular calcification through the inhibition of osteogenic signaling and matrix vesicle release. Biochem Biophys Res Commun. 2014;451(3):436-41. https://doi.org/10.1016/j.bbrc.2014.08.007.

33. Jaminon A, Reesink K, Kroon A, Schurgers L. The Role of vascular smooth muscle cells in arterial remodeling: focus on calcification-related processes. Int J Mol Sci. 2019;20(22):5694. https://doi.org/10.3390/ijms2 0225694.

34. Peng YQ, Xiong D, Lin X, Cui RR, Xu F, Zhong JY, Zhu T, Wu F, Mao MZ, Liao XB, et al. Oestrogen inhibits arterial calcification by promoting autophagy. Sci Rep. 2017;7(1):3549. https://doi.org/10.1038/ s41598-017-03801-X.

35. Liu D, Cui W, Liu B, Hu H, Liu J, Xie R, Yang X, Gu G, Zhang J, Zheng $H$. Atorvastatin protects vascular smooth muscle cells from TGF- $\beta 1$ stimulated calcification by inducing autophagy via suppression of the $\beta$-catenin pathway. Cell Physiol Biochem. 2014;33(1):129-41. https://doi. org/10.1159/000356656.

36. Yang R, Zhu Y, Wang Y, Ma W, Han X, Wang X, Liu N. HIF-1a/PDK4/ autophagy pathway protects against advanced glycation end-products induced vascular smooth muscle cell calcification. Biochem Biophys Res Commun. 2019;517(3):470-6. https://doi.org/10.1016/j.bbrc.2019.07.102.

37. XuTH, Qiu XB, Sheng ZT, Han YR, Wang J, Tian BY, Yao L. Restoration of microRNA-30b expression alleviates vascular calcification through the mTOR signaling pathway and autophagy. J Cell Physiol. 2019;234(8):14306-18. https://doi.org/10.1002/jcp.28130. [published correction appears in J Cell Physiol. 2020 Sep;235(9):6323-6324]

38. Liang QH, Jiang Y, Zhu X, Cui RR, Liu GY, Liu Y, Wu SS, Liao XB, Xie H, Zhou HD, et al. Ghrelin attenuates the osteoblastic differentiation of vascular smooth muscle cells through the ERK pathway. PLoS ONE. 2012;7(4):e33126. https://doi.org/10.1371/journal.pone.0033126.

39. Chen K, Zhou X, Sun Z. Haplodeficiency of klotho gene causes arterial stiffening via upregulation of scleraxis expression and induction of autophagy. Hypertension. 2015;66(5):1006-13. https://doi.org/10.1161/ hypertensionaha. 115.06033.

40. Zhang X, Chen J, Meng Q, Li D, Hu FZ, Zhu YQ, Huang YY, Liu YN, Sun L, Liang QH. The protective effects of long non-coding RNA-ANCR on arterial calcification. J Bone Miner Metab. 2020;38(4):421-31. https://doi.org/ 10.1007/s00774-019-01076-y.

41. Antonopoulos AS, Margaritis M, Lee R, Channon K, Antoniades C. Statins as anti-inflammatory agents in atherogenesis: molecular mechanisms and lessons from the recent clinical trials. Curr Pharm Des. 2012;18(11):1519-30. https://doi.org/10.2174/138161212799504803.

42. Shibasaki M, Wang JG, Figueiredo JL, New SE, Quillard T, Goettsch C, Koga J, Sonoki H, Matsumoto J, Aikawa M, et al. Pitavastatin reduces inflammation in atherosclerotic plaques in apolipoprotein E-deficient mice with late stage renal disease. PLOS ONE. 2015;10(9): e0138047. https://doi.org/10.1371/journal.pone.0138047.

43. Kleinauskienè R, Jonkaitienè R. Degenerative aortic stenosis, dyslipidemia and possibilities of medical treatment. Medicina (Kaunas). 2018;54(2):24. https://doi.org/10.3390/medicina54020024.

44. Okuyama H, Langsjoen PH, Hamazaki T, Ogushi Y, Hama R, Kobayashi T, Uchino H. Statins stimulate atherosclerosis and heart failure: pharmacological mechanisms. Expert Rev Clin Pharmacol. 2015;8(2):189-99. https://doi.org/10.1586/17512433.2015.1011125. [published correction appears in Expert Rev Clin Pharmacol. 2015;8(4):503-5]

45. Tintut Y, Hsu JJ, Demer LL. Lipoproteins in cardiovascular calcification: potential targets and challenges. Front Cardiovasc Med. 2018;5:172. https://doi.org/10.3389/fcvm.2018.00172.

46. Zhu Y, Ma WQ, Han XQ, Wang Y, Wang X, Liu NF. Advanced glycation end products accelerate calcification in VSMCs through HIF-1a/PDK4 activation and suppress glucose metabolism. Sci Rep. 2018;8(1):13730. https:// doi.org/10.1038/s41598-018-31877-6.

47. Mackenzie NC, Staines KA, Zhu D, Genever P, Macrae VE. miRNA-221 and miRNA-222 synergistically function to promote vascular calcification Cell Biochem Funct. 2014;32(2):209-16. https://doi.org/10.1002/cbf. 3005.

48. Louvet L, Metzinger L, Büchel J, Steppan S, Massy ZA. Magnesium attenuates phosphate-induced deregulation of a MicroRNA signature and prevents modulation of Smad1 and Osterix during the course of Vascular calcification. Biomed Res Int. 2016;2016:7419524. https://doi. org/10.1155/2016/7419524.

49. Wang J, Sun YT, XuTH, Sun W, Tian BY, Sheng ZT, Sun L, Liu LL, Ma JF, Wang LN, et al. MicroRNA-30b regulates high phosphorus level-induced autophagy in vascular smooth muscle cells by targeting BECN1. Cell Physiol Biochem. 2017;42(2):530-6. https://doi.org/10.1159/000477602.

50. Xu M, Liu L, Song C, Chen W, Gui S. Ghrelin improves vascular autophagy in rats with vascular calcification. Life Sci. 2017;179:23-9. https://doi.org/ 10.1016/j.lfs.2016.11.025.

51. Chen J, Gu Y, Zhang H, Ning Y, Song N, Hu J, Cai J, Shi Y, Ding X, Zhang X. Amelioration of uremic toxin indoxyl sulfate-induced osteoblastic calcification by SET domain containing lysine methyltransferase $7 / 9$ protein. Nephron. 2019;141(4):287-94. https://doi.org/10.1159/000495885.

52. Sun Y, Byon CH, Yang Y, Bradley WE, Dell'Italia LJ, Sanders PW, Agarwal $\mathrm{A}, \mathrm{Wu} \mathrm{H}$, Chen Y. Dietary potassium regulates vascular calcification and arterial stiffness. JCl Insight. 2017;2(19): e94920. https://doi.org/10.1172/ jci.insight.94920.

53. Song Z, Wei D, Chen Y, Chen L, Bian Y, Shen Y, Chen J, Pan Y. Association of astragaloside IV-inhibited autophagy and mineralization in vascular smooth muscle cells with IncRNA H19 and DUSP5-mediated ERK signaling. Toxicol Appl Pharmacol. 2019;364:45-54. https://doi.org/10.1016/j. taap.2018.12.002.

54. VoelkI J, Lang F, Eckardt KU, Amann K, Kuro-O M, Pasch A, Pieske B, Alesutan I. Signaling pathways involved in vascular smooth muscle cell calcification during hyperphosphatemia. Cell Mol Life Sci. 2019;76(11):207791. https://doi.org/10.1007/s00018-019-03054-z.

55. Grootaert MOJ, Moulis M, Roth L, Martinet W, Vindis C, Bennett MR, De Meyer GRY. Vascular smooth muscle cell death, autophagy and 
senescence in atherosclerosis. Cardiovasc Res. 2018;114(4):622-34. https://doi.org/10.1093/cvr/cvy007.

56. Di M, Wang L, Li M, Zhang Y, Liu X, Zeng R, Wang H, Chen Y, Chen W, Zhang $Y$, et al. Dickkopf1 destabilizes atherosclerotic plaques and promotes plaque formation by inducing apoptosis of endothelial cells through activation of ER stress. Cell Death Dis. 2017;8(7): e2917. https:// doi.org/10.1038/cddis.2017.277.

57. Rodriguez KJ, Piechura LM, Porras AM, Masters KS. Manipulation of valve composition to elucidate the role of collagen in aortic valve calcification. BMC Cardiovasc Disord. 2014;14:29. https://doi.org/10.1186/ 1471-2261-14-29.

58. Ciceri P, Elli F, Braidotti P, Falleni M, Tosi D, Bulfamante G, Block GA, Cozzolino M. Iron citrate reduces high phosphate-induced vascular calcification by inhibiting apoptosis. Atherosclerosis. 2016;254:93-101. https:// doi.org/10.1016/j.atherosclerosis.2016.09.071.

59. Chen WR, Yang JQ, Liu F, Shen XQ, Zhou YJ. Melatonin attenuates vascular calcification by activating autophagy via an AMPK/mTOR/ULK1 signaling pathway. Exp Cell Res. 2020;389(1):111883. https://doi.org/10. 1016/j.yexcr.2020.111883.

60. He HQ, Law BYK, Zhang N, Qiu CL, Qu YQ, Wu AG, Han Y, Song Q, Zheng WL, Liu Y, et al. Bavachin protects human aortic smooth muscle cells against $\beta$-Glycerophosphate-mediated vascular calcification and apoptosis via activation of mTOR-dependent autophagy and suppression of $\beta$-Catenin signaling. Front Pharmacol. 2019;10:1427. https://doi.org/10. 3389/fphar.2019.01427.

61. Ciceri P, Falleni M, Tosi D, Martinelli C, Cannizzo S, Marchetti G, D'Arminio Monforte A, Bulfamante G, Block GA, Messa P, et al. Therapeutic effect of iron citrate in blocking calcium deposition in high Pi-calcified VSMC: role of autophagy and apoptosis. Int J Mol Sci. 2019;20(23):5925. https://doi. org/10.3390/ijms20235925.

62. Ciceri P, Elli F, Cappelletti L, Tosi D, Braidotti P, Bulfamante G, Cozzolino M. A new in vitro model to delay high phosphate-induced vascular calcification progression. Mol Cell Biochem. 2015;410(1-2):197-206. https:// doi.org/10.1007/s11010-015-2552-6.

63. Ma WQ, Sun XJ, Wang Y, Zhu Y, Han XQ, Liu NF. Restoring mitochondrial biogenesis with metformin attenuates $\beta$-GP-induced phenotypic transformation of VSMCs into an osteogenic phenotype via inhibition of PDK4/oxidative stress-mediated apoptosis. Mol Cell Endocrinol. 2019;479:39-53. https://doi.org/10.1016/j.mce.2018.08.012.

64. Zhu Y, Han XQ, Sun XJ, Yang R, Ma WQ, Liu NF. Lactate accelerates vascular calcification through NR4A1-regulated mitochondrial fission and BNIP3-related mitophagy. Apoptosis. 2020;25(5-6):321-40. https://doi. org/10.1007/s10495-020-01592-7.

65. Zhu Y, Ji JJ, Yang R, Han XQ, Sun XJ, Ma WQ, Liu NF. Lactate accelerates calcification in VSMCs through suppression of BNIP3-mediated mitophagy. Cell Signal. 2019;58:53-64. https://doi.org/10.1016/j.cellsig. 2019.03.006.

66. Saito T, Sadoshima J. Molecular mechanisms of mitochondrial autophagy/mitophagy in the heart. Circ Res. 2015;116(8):1477-90. https://doi.org/10.1161/circresaha.116.303790.

67. Gudipaty SA, Conner CM, Rosenblatt J, Montell DJ. Unconventional ways to live and die: cell death and survival in development, homeostasis, and disease. Annu Rev Cell Dev Biol. 2018;34:311-32. https://doi.org/10. 1146/annurev-cellbio-100616-060748.

68. Wang L, Li X, Yang Z, Zhu M, Xie J. Autophagy induced by low concentrations of crotonaldehyde promotes apoptosis and inhibits necrosis in human bronchial epithelial cells. Ecotoxicol Environ Saf. 2019;167:16977. https://doi.org/10.1016/j.ecoenv.2018.10.008.

69. Alves RD, Eijken M, van de Peppel J, van Leeuwen JP. Calcifying vascular smooth muscle cells and osteoblasts: independent cell types exhibiting extracellular matrix and biomineralization-related mimicries. BMC Genomics. 2014;15(1):965. https://doi.org/10.1186/ 1471-2164-15-965.

70. Zhu YS, Gu Y, Jiang C, Chen L. Osteonectin regulates the extracellular matrix mineralization of osteoblasts through P38 signaling pathway. J Cell Physiol. 2020;235(3):2220-31. https://doi.org/10.1002/jcp.29131.

71. Wasilewski GB, Vervloet MG, Schurgers LJ. The bone-vasculature axis: calcium supplementation and the role of Vitamin K. Front Cardiovasc Med. 2019;6:6. https://doi.org/10.3389/fcvm.2019.00006.
72. Vassalle C, Mazzone A. Bone loss and vascular calcification: A bidirectional interplay? Vascul Pharmacol. 2016;86:77-86. https://doi. org/10.1016/j.vph.2016.07.003.

73. van Ballegooijen AJ, Pilz S, Tomaschitz A, Gübler MR, Verheyen $\mathrm{N}$. The Synergistic interplay between Vitamins D and K for bone and cardiovascular health: a narrative review. Int J Endocrinol. 2017:2017:7454376. https://doi.org/10.1155/2017/7454376.

74. Sivaraj KK, Adams RH. Blood vessel formation and function in bone. Development. 2016;143(15):2706-15. https://doi.org/10.1242/dev. 136861.

75. De Maré A, Maudsley S, Azmi A, Hendrickx JO, Opdebeeck B, Neven $E, D^{\prime}$ Haese PC, Verhulst A. Sclerostin as regulatory molecule in vascular media calcification and the bone-vascular axis. Toxins (Basel). 2019;11(7):428. https://doi.org/10.3390/toxins11070428.

76. Borland SJ, Morris TG, Borland SC, Morgan MR, Francis SE, Merry CLR, Canfield AE. Regulation of vascular smooth muscle cell calcification by syndecan-4/FGF-2/PKCa signalling and cross-talk with TGF $\beta$. Cardiovasc Res. 2017;113(13):1639-52. https://doi.org/10.1093/cvr/ $\mathrm{CV} \times 178$.

77. Nollet M, Santucci-Darmanin S, Breuil V, Al-Sahlanee R, Cros C, Topi M, Momier D, Samson M, Pagnotta S, Cailleteau L, et al. Autophagy in osteoblasts is involved in mineralization and bone homeostasis. Autophagy. 2014;10(11):1965-77. https://doi.org/10.4161/auto.36182.

78. Duan ZX, Tu C, Liu Q, Li SQ, Li YH, Xie P, Li ZH. Adiponectin receptor agonist AdipoRon attenuates calcification of osteoarthritis chondrocytes by promoting autophagy. J Cell Biochem. 2020;121(5-6):333344. https://doi.org/10.1002/jcb.29605.

79. Vrahnas C, Blank M, Dite TA, Tatarczuch L, Ansari N, Crimeen-Irwin B, Nguyen $\mathrm{H}$, Forwood MR, Hu Y, Ikegame M, et al. Increased autophagy in EphrinB2-deficient osteocytes is associated with elevated secondary mineralization and brittle bone. Nat Commun. 2019;10(1):3436. https://doi.org/10.1038/s41467-019-11373-9. [published correction appears in Nat Commun. 2019 Nov 4;10(1):5073]

80. Khaminets A, Heinrich T, Mari M, Grumati P, Huebner AK, Akutsu M, Liebmann L, Stolz A, Nietzsche S, Koch N, et al. Regulation of endoplasmic reticulum turnover by selective autophagy. Nature. 2015;522(7556):354-8. https://doi.org/10.1038/nature14498.

81. Zaglia T, Milan G, Ruhs A, Franzoso M, Bertaggia E, Pianca N, Carpi A, Carullo P, Pesce P, Sacerdoti D, et al. Atrogin-1 deficiency promotes cardiomyopathy and premature death via impaired autophagy. J Clin Invest. 2014;124(6):2410-24. https://doi.org/10.1172/jci66339.

82. Gawlik KI, Durbeej M. A Family of laminin a2 chain-deficient mouse mutants: advancing the research on LAMA2-CMD. Front Mol Neurosci. 2020;13:59. https://doi.org/10.3389/fnmol.2020.00059.

83. Choe SC, Hamacher-Brady A, Brady NR. Autophagy capacity and sub-mitochondrial heterogeneity shape Bnip3-induced mitophagy regulation of apoptosis. Cell Commun Signal. 2015;13:37. https://doi. org/10.1186/s12964-015-0115-9.

84. Buraschi S, Neill T, Goyal A, Poluzzi C, Smythies J, Owens RT, Schaefer $\mathrm{L}$, Torres A, lozzo RV. Decorin causes autophagy in endothelial cells via Peg3. Proc Natl Acad Sci U S A. 2013;110(28):E2582-91. https://doi. org/10.1073/pnas.1305732110.

85. Schoenherr C, Serrels B, Proby C, Cunningham DL, Findlay JE, Baillie GS, Heath JK, Frame MC. Eps8 controls Src- and FAK-dependent phenotypes in squamous carcinoma cells. J Cell Sci. 2014;127(Pt 24):5303-16. https://doi.org/10.1242/jcs.157560.

86. Magor GW, Tallack MR, Gillinder KR, Bell CC, McCallum N, Williams B, Perkins AC. KLF1-null neonates display hydrops fetalis and a deranged erythroid transcriptome. Blood. 2015;125(15):2405-17. https://doi.org/ 10.1182/blood-2014-08-590968.

87. Hachez C, Veljanovski V, Reinhardt H, Guillaumot D, Vanhee C, Chaumont F, Batoko H. The Arabidopsis abiotic stress-induced TSPO-related protein reduces cell-surface expression of the aquaporin PIP2;7 through protein-protein interactions and autophagic degradation. Plant Cell. 2014;26(12):4974-90. https://doi.org/10.1105/tpc.114. 134080.

88. Plissonnier ML, Lahlali T, Raab M, Michelet M, Romero-López C, Rivoire M, Strebhardt K, Durantel D, Levrero M, Mehlen P, et al. Reciprocal antagonism between the netrin-1 receptor 
uncoordinated-phenotype-5A (UNC5A) and the hepatitis C virus Oncogene. 2017;36(48):6712-24. https://doi.org/10.1038/onc.2017. 271.

89. Li W, Zhang S, Liu J, Liu Y, Liang Q. Vitamin K2 stimulates MC3T3-E1 osteoblast differentiation and mineralization through autophagy induction. Mol Med Rep. 2019;19(5):3676-84. https://doi.org/10.3892/ mmr.2019.10040

90. Cinque L, Forrester A, Bartolomeo R, Svelto M, Venditti R, Montefusco S, Polishchuk E, Nusco E, Rossi A, Medina DL, et al. FGF signalling regulates bone growth through autophagy. Nature. 2015;528(7581):272-5. https://doi.org/10.1038/nature16063.

91. Hegner B, Schaub T, Janke D, Zickler D, Lange C, Girndt M, Jankowski J, Schindler R, Dragun D. Targeting proinflammatory cytokines ameliorates calcifying phenotype conversion of vascular progenitors under uremic conditions in vitro. Sci Rep. 2018:8(1):12087. https://doi.org/10. 1038/s41598-018-30626-z.

92. Carracedo M, Persson O, Saliba-Gustafsson P, Artiach G, Ehrenborg E, Eriksson P, Franco-Cereceda A, Bäck M. Upregulated autophagy in calcific aortic valve stenosis confers protection of valvular interstitial cells. Int J Mol Sci. 2019:20(6):1486. https://doi.org/10.3390/ijms2 0061486.

93. Deng XS, Meng X, Venardos N, Song R, Yamanaka K, Fullerton D, Jaggers J. Autophagy negatively regulates pro-osteogenic activity in human aortic valve interstitial cells. J Surg Res. 2017;218:285-91. https://doi.org/10.1016/j.jss.2017.05.088.

94. Schaub T, Gürgen D, Maus D, Lange C, Tarabykin V, Dragun D, Hegner B. mTORC1 and mTORC2 differentially regulate cell fate programs to coordinate osteoblastic differentiation in mesenchymal stromal cells. Sci Rep. 2019;9(1):20071. https://doi.org/10.1038/s41598-019-56237w. [published correction appears in Sci Rep. 2020 Feb 25;10(1):3740]

95. Xu L, Xu K, Wu Z, Chen Z, He Y, Ma C, Moqbel SAA, Ran J, Zhang C, Wu $L$, et al. Pioglitazone attenuates advanced glycation end productsinduced apoptosis and calcification by modulating autophagy in tendon-derived stem cells. J Cell Mol Med. 2020;24(3):2240-51. https://doi.org/10.1111/jcmm.14901.

96. Chen NX, O'Neill KD, Moe SM. Matrix vesicles induce calcification of recipient vascular smooth muscle cells through multiple signaling pathways. Kidney Int. 2018;93(2):343-54. https://doi.org/10.1016/j. kint.2017.07.019.
97. Bakhshian Nik A, Hutcheson JD, Aikawa E. Extracellular vesicles as mediators of cardiovascular calcification. Front Cardiovasc Med. 2017;4:78. https://doi.org/10.3389/fcvm.2017.00078.

98. Zazzeroni L, Faggioli G, Pasquinelli G. Mechanisms of Arterial Calcification: The Role of Matrix Vesicles. Eur J Vasc Endovasc Surg. 2018;55(3):425-32. https://doi.org/10.1016/j.ejvs.2017.12.009.

99. Mizushima N, Komatsu M. Autophagy: renovation of cells and tissues. Cell. 2011;147(4):728-41. https://doi.org/10.1016/j.cell.2011.10.026.

100. Cuomo F, Altucci L, Cobellis G. Autophagy Function and Dysfunction: Potential Drugs as Anti-Cancer Therapy. Cancers. 2019;11:1465. https://doi.org/10.3390/cancers11101465.

101. Chude Cl, Amaravadi RK. Targeting Autophagy in Cancer: Update on Clinical Trials and Novel Inhibitors. International Journal of Molecular Sciences. 2017;18:1279. https://doi.org/10.3390/ijms18061279.

102. Ávalos Y, Canales J, Bravo-Sagua R, Criollo A, Lavandero S, Andrew F. G. Quest. Tumor Suppression and Promotion by Autophagy. BioMed Research International. 2014; 603980-95. https://doi.org/10.1155/ 2014/603980

103. Raggi P, Bellasi A, Bushinsky D, Bover J, Rodriguez M, Ketteler M, Sinha S, Salcedo C, Gillotti K, Chertow GM. Slowing Progression of Cardiovascular Calcification With SNF472 in Patients on Hemodialysis. Circulation. 2020;141:728-39. https://doi.org/10.1161/CIRCULATIO NAHA.119.044195.

104. Hedayati SS. A Novel Treatment for Vascular Calcification in Patients With Dialysis-Dependent Chronic Kidney Disease. Circulation. 2020;141:740-2. https://doi.org/10.1161/CIRCULATIONAHA.119. 044801.

105. Anekonda TS, Wadsworth TL, Sabin R, Frahler K, Harris C, Petriko B, Ralle M, Woltjer R, Quinn JF. Phytic acid as a potential treatment for Alzheimer's pathology: evidence from animal and in vitro models. J Alzheimers Dis. 2011:23(1):21-35. https://doi.org/10.3233/ JAD-2010-101287.

\section{Publisher's Note}

Springer Nature remains neutral with regard to jurisdictional claims in published maps and institutional affiliations.
Ready to submit your research? Choose BMC and benefit from:

- fast, convenient online submission

- thorough peer review by experienced researchers in your field

- rapid publication on acceptance

- support for research data, including large and complex data types

- gold Open Access which fosters wider collaboration and increased citations

- maximum visibility for your research: over $100 \mathrm{M}$ website views per year

At $\mathrm{BMC}$, research is always in progress.

Learn more biomedcentral.com/submissions 